\title{
Sex and the Missionary Position: The Grammar of Philippine Colonial Sexualities as a Locus of Translation
}

\author{
Marlon James Sales \\ Monash University, Australia
}

\section{Introduction}

The written history of Hispanic Philippines is a story wrought in translation. Colonial accounts about this Southeast Asian archipelago attempted to make sense of its people and their cultures by translating them for a European readership in a period that spanned more than three centuries. While there were indeed a number of colonial administrators, travellers and other lay chroniclers who mentioned the country in their writings, it is in the texts penned by missionary priests that we find the earliest and most extensive intent to systematize the understanding of Filipinos on the basis of their languages and customs. From the very beginning of Spain's colonial expansion in Asia in the 1500s until the last year of the Empire in 1898 when the Philippines was finally ceded to the United States, members of various religious orders wrote histories that recounted how their brothers in the cloth preached the Christian doctrine to different ethnolinguistic groups in the country and the rest of the Asian continent. They similarly wrote grammars and dictionaries, the primary purpose of which was to help ministers in the administration of the sacraments and rituals of the Roman Church in the islands' many vernaculars.

The colonization of the Philippines was unique in that although it was essentially a profitless venture for Spain, the Spanish Crown maintained it as a strategic trading post in the Pacific and as a missionary springboard to Asia (Kamen 203-06). That the archipelago was a bastion of the Christian mission in the continent was made very clear in missionary writings. For example, Francisco Colín recalled that fellow Jesuits in the Philippines who were by then "working opportunely in the islands of Maluco, Japan, and the Kingdom of China for the spiritual health of souls." "Fray Diego Francisco de Aduarte, on the other hand, claimed that the

Dominican province of the Most Holy Rosary was founded in Asia "for the conversion of the Philippines and the great China."2

The impact of missionaries to colonial life on both sides of the Pacific was immense. The clergy "touched every walk of life. They were the teachers, architects, engineers, moral censors, writers and scientists of the colonial period" (Crow 209). Early Filipinos were resettled in villages called reducciones, which were constructed around a church (Crossley 22; García Abasolo 196).

\footnotetext{
1 “trabajauan dichosamente en las Islas del Maluco, y Iapon, y en el Reyno de la China en la salud espiritual de las almas" (Colín n.p.). Unless otherwise specified, all citations from both Tagalog and Spanish have been translated to English by myself. Except for the long $\mathrm{s}(\delta)$, which has been changed to $s$, the orthographic features of the source texts (i.e., $u$ instead of $v / b$, untitled graphemes, etc.) have been retained.

2 "para la conversion de Filipinas, y la gran China" (Aduarte 8)
} 
Colonial life revolved around this church as these reducciones were built "bajo las campanas, that is, within the hearing of the church bells" (Phelan 49). Priests in the communities performed both religious and secular tasks, and were a constant presence in the lives of the people from birth to burial. And given that not too many Spaniards were able to settle in this periphery in the Orient because of its distance from the colonial metropolis and the American mainland, the priest was the closest contact that many Filipinos had with the Madre Patria. The priest for many Filipinos was Spain.

\section{Sacramentalizing Sex}

Such a direct contact with the indigenous people was made manifest in the grammatical and lexical production of the missionaries. Despite royal decrees to use Castilian in the Christianization of the colonies, the missionary experience in the Americas led priests to employ the local vernaculars in proselytizing Filipinos. The Church became the safeguard of indigenous languages (Franco Figueroa 39) because of its role in mapping out and recording the linguistic knowledge of the colonies through the publication of colonial grammars. A total of 124 grammars and 108 vocabularies were published on 15 Philippine languages by the end of the Spanish colonial rule, an impressive number that equalled or even surpassed the outputs in the New World (Sueiro Justel 171).

Grammar in the missionary-colonial sense is, of course, problematic (Zwartjes 8-10; Zimmermann 111, 116), and there is a danger of glossing over the peculiarities of these writings if we are to apply our contemporary definitions of grammar as system of rules or as a text that compiles such rules. For one, there was a clear religious and missional skopos in writing missionary grammars. It was for this reason that linguistic exemplars in colonial grammars and dictionaries often contained references to Christian dogma and morality. Terms that referred to the Christian God, the Virgin Mary and the saints were generally held as untranslatable (Zimmermann 118), and were thus rendered in Castilian (Caceres-Lorenzo 795-96; GarcíaMedall 211). Local languages were believed to be insufficient in understanding the mysteries of the Christian faith (Ricard 51), and any similarities between Christianity and the pre-Hispanic religion were seen as diabolical (Phelan 53; see also López de Mariscal). A specific example of this can be gathered from a 1731 manual for priests in the Philippines written by Fray Thomas (Tomás) Ortiz. In this text, the Augustinian cautioned missionaries against using the Tagalog term tavong bininyagan 'baptized man', and suggested instead that tavong Christiano 'Christian man' be used (3-4). Bininyagan was derived from the word binyag, which in turn referred to the act of splashing water that even non-Christian Filipinos performed (Noceda and Sanlúcar 61). The priest-author must have felt that the preHispanic ritual was incongruent to the Christian sacrament of initiation into the faith, and went on to declare that all languages of the islands were "ciertamente nulas" 'certainly void' with respect to the Christian religion, and that code-switching to Latinate terms was a recourse that was "mas facil, $y$ decente" 'easier and more decent'. Another peculiarity of missionary grammars was its dependence on Latin as an epistemological framework. The languages of the colonies were broken down into the categories of Latin, and were generally explained using Castilian as metalanguage (Esparza Torres 6-7; Zimmermann 11011) in a process called exo-grammatization (Auroux 35). The 
grammatical categories and processes of Latin such as case, mood, tense and declensions were employed to reduce the languages into rules that could be taught and replicated (Sales 84-85).

For all these reasons, the grammatization of a language was as an act of translation itself. Although current scholarship in missionary linguistics seems to suggest that the translation of missionary-colonial texts in the form of doctrinas 'catecheses' and confesionarios 'confession guides' was a process that was both different from but contingent upon the grammatization of a language through the publication of its artes 'grammars' and vocabularios 'dictionaries', the approaches employed by the missionaries to carry out both processes were decidedly translational. Translation, after all, "refers not only to the transfer of specific texts into European languages, but to all the practices whose aim was to compact and reduce an alien reality into the terms imposed by a triumphant Western culture" (Simon 11). Through exemplars illustrating grammatical or lexical usage, the missionaries offered their portrayal of early Filipino societies, and provided their depiction of the colony in the Far East for the understanding of the imperial metropolis.

As such, it comes as no surprise that some of the most primordial written descriptions of Filipino sexual desires can also be traced to these missionary writings. Translating sexualities within the context of Hispanic Philippines is an important point of inquiry because "[s]ex is a profoundly semantic act. Like language, it is subject to the shaping force of social convention, rules of proceeding, and accumulated precedent" (Steiner 38). In contemporary Philippine culture where sex is largely held as a linguistic taboo, Filipinos are wont to use code-switching, euphemisms, and other similar linguistic devices to express sexuality. Any direct discursive reference to sexual acts or the human body can be considered vulgar.

Such reticence against sex is in no way exclusive to Philippine contemporary society, for similar tensions can be detected in missionary-colonial texts. It was not uncommon for early Filipinos to be routinely described as obstinate and sinful in missionary writings, and priests were often admonished to correct them and lead them to the path of Christian salvation. Franciscan friar Juan Francisco de San Antonio, for instance, writes in his history that,

[i]f all these aforementioned contradictions of the Indios are born out of their perversity or lack of ability, let them be examined by whoever so desires, for I have seen new contradictions. Some of their actions, which appear naïve, are in fact doubly perverse, and this also happens at times in the reverse. Ultimately, be they perverse or naïve, theirs is a stubborn temperament. Great then is the merit that the ministers of doctrine have. ${ }^{3}$

Elsewhere, Jesuit chronicler Pedro Chirino notes that Filipinos ought to be brought to the light after being blinded by idolatry. He further suggests that such blindness happened through language: the Filipinos did not use written letters to talk about religion, and instead based their

\footnotetext{
3 “ [s]i todas las cõtrariedades referidas de los Indios son de malicia, ô de sus faltas de capacidades, examinelo quien quisiere, que aun en esto tengo yo vistas nuevas contrariedades; pues vnas acciones, q parecen de simples, son malicias muy dobles; y sucede tambien al contrario otras veces. Y en fin por maliciosos, ô por simples, su Genio inapeâble; y por esso muy grande el mérito, que los Ministros de Doctrina tienen." (San Antonio Part I, Book I, Chapter XL, 142)
} 
beliefs on a tradition that - it was claimed — the Devil himself introduced by speaking with their idols, priests and priestesses:

Despite entering into the dark chasm of blindness caused by idolatry, I am able to see a disorderly melange of things most vile, abominable and worthy of their deviser. And even though in burrowing through the wall within this infernal cavern I encounter unwieldy, repulsive and hellish vermin, I am able with the light of truth to reduce them to order, so that we who in opening our eyes find ourselves in the light of faith can praise God Almighty and take pity on the blind who in darkness love such evils and hold them in esteem, without being able to open their eyes to another light. And so I shall first talk about the false seduction possessed by the divinity of their idols. Second, I shall talk about their priests and priestesses. Third, I shall finally talk about their sacrifices and superstitions. In neither one of these three things, nor in those concerning governance and polity have their letters been of use to them, for they have never used them save for when they wrote letters to each other, as we have said. Their government and religion are established in their tradition and usage, having been introduced by the Devil himself who spoke to them through their idols and ministers... ${ }^{4}$

These themes in missionary writing extended even to the discussion of sexual practices. As in the case of the pre-Hispanic religion, Philippines colonial sexualities were imagined from a perspective of difference, and were reported as lurid abominations. Take this example from an anonymous 1898 text written in defence of Spanish missionaries in the Philippines:

When the Spaniards arrived in the archipelago, the natives, as already mentioned, were complete savages. In fact they lived in miserable huts. They usually did not wear anything else except for loincloths. They were proud of their drinking sprees. Infanticides were common. Virginity seemed to degrade them, and they tried to lose it before reaching puberty. There were deflowerers by profession! They knew no money, although there were objects that were exchanged as such, among which were men, women and children.

They spent their lives waging wars among themselves, and the prisoner whose neck they would save from death would be reduced forthwith to dreadful slavery. ${ }^{5}$

\footnotetext{
4 "Aunque al entrar en la Sima escura de tanta ceguedad de Idolatria; hallo una confusion desordenada de cosas vilissisimas, abominables, $i$ dignas del inventor della. I aunque al escarvar la pared dentro desta cueva infernal; descubro infinitas savandijas torpes, asquerosas, $i$ verdaderamente infernales. Con la luz de la verdad se me ofrece reduzirlas a metodo: para que alabemos al todo poderoso Dios los que en abriendo los ojos, nos hallamos en la de la fe, i nos compadezcamos de los que ciegos cõ sus tinieblas las aman, $i$ estiman, sin saber abrir los ojos a otra luq. Assi dire primero de lo que toca a la persuasion falsa, que tienen de la divinidad de sus Idolos. Segundo, de sus sacerdotes, i sacerdotisas. Tercer, $i$ ultimo, de sus sacrificios, i supersticiones. Para ninguna destas tres cosas, ni de las de govierno, i polizia [...] no les servian sus letras: por que jamas an usado dellas, mas que para cartearse, como diximos. Todo su gobierno, $i$ Religion, se funda en tradicion, $i$ en uso introdurido del mismo demonio, que les hablaba en sus Idolos, i en sus ministros... (Chirino 52)

5 “[C] uando llegaron los españoles al Archipiélago, eran sus naturales—como queda dicho—unos completos salvajes. En efecto; moraban en chozas miserables. No vestian, por lo común, más prendas que el taparrabo. Tenían á gala la borrachera. En ellas, el infanticidio era cosa corriente: pareciales deshonrosa la virginidad, y procuraban perderla antes de llegar á púberes; —ibabia desfloradores de profesión! No conocian la moneda, aunque existian objetos que por moneda corrían, y entre esos objetos, hombres, mujeres y niños. Pasábanse la vida
} 
Early Filipinos were depicted as savages who thrived in violence and lust. Some paragraphs later, the anonymous author would proceed to claim that civilization entered the Philippines through the Spanish colonial rule with the help of the religious orders.

It can hence be said that, "[ $[$ ]he conquest and settlement of the New World posed special problems for the Iberian Church and state [...], creating a unique experiment in cultural adaptation of sexual behavior" (Lavrín "Introduction" 3). In a milieu where two worlds and two languages came in contact for the first time, the notions of something as intimate as sexuality would necessarily be confronted, interrogated and mediated through the prisms of cultures, or more specifically, through the prisms of a dominant and dominating culture. The colonial construction of sexuality in Hispanic Philippine thus formed a locus of translation where translating sexual desire became "a political act, with important rhetorical and ideological implications" (Santaemilia 12526).

While the "deviant" sexual behaviour of colonized Filipinos was consistently criticized in missionary linguistics, "alternative" and "unorthodox" sexualities were not entirely unheard of in Catholic Spain. Cases of promiscuity, infidelity, homosexuality, bestiality and the like were well documented and prosecuted by both civil and religious authorities in Europe and the New World (Garza Carvajal). But since "[c]olonialism, like other dominant discourses, alternately fetishized and feared its Others" (Tiffin and Lawson 5), one only can surmise that the Spaniards' interest for indigenous sexual practices stemmed not from their fascination for the sexual act per se, but rather from their imaginary of the colonized subjects, who participated in the performance of such acts. And so, while it has to be recognized that missionary writers were presenting their arguments based on the prevalent knowledge systems during a time when the Christian message was seen as the absolute truth and colonization was accepted as a civilizing and redemptive force, the translational exemplars that we shall later on see suggest that distinctions were somehow made between the colonizer and the colonized in describing the sexual desires of the latter. In other words, the colonial pronouncements that Filipino women were a licentious lot who easily gave in to sex whenever a good sum of money was offered (Morga 174), or that the practice among Filipino men of wearing penile rings to enhance their sexual prowess was the work of the Devil (Anonymous Manners, Customs and Beliefs 332-33), etc., sexualized and exoticized the colonial Other. The colonies "provided a site for European pornographic fantasies [...], with lurid descriptions of sexual license, promiscuity, gynecological aberrations, and general perversion marking the Otherness of the colonized for metropolitan consumption" (Stoler 43). The translational space created by the missionary writer in his capacity as a historian, grammarian or lexicographer textualized the carnal pleasures of early Filipinos, and presented an exoticized and fetishized image of indigenous desires to a readership that was invited to voyeuristically share in this space and consume such image. The missionary writer was "actually constructing an image of a literature or a culture to be consumed

haciéndose la guerra las unas rancherias á las otras, y al prisionero que le perdonaban el pescuezo, reducianlo en el acto á la más espantosa esclavitud." (Anonymous Los frailes filipinos 22) 
by readers of another culture" (Mukherjee 137). His version of Filipino colonial sexualities was the version of Filipino colonial sexualities that is read, studied and referenced, and through which the idea of colonial civility was articulated (see, for example, Cronin 230; Garza Carvajal 4 and passim).

\section{Sexual(ized) Dishonesties}

For the purposes of this essay, I have chosen to limit my discussion to three core texts of Philippine missionary linguistics. All three were written (although not exclusively) on and in Tagalog, the basis of the modern-day national language called Filipino. In gathering my data, I have made some very broad groupings of words that sounded discursively obscene in contemporary Filipino. I have located these fields in the texts by searching purposively for their possible translations, and by performing back-translations as a verificatory procedure.

The first text I have examined was the 1832 edition of the Vocabulario de la lengua tagala by Jesuit lexicographers Juan de Noceda and Pedro de Sanlúcar, considered to be the most authoritative dictionary of the colonial period (Retana 22). I have also analyzed the 1745 Arte de la lengua tagala, y manual tagalog, para la administracion de los santos sacramentos by the Franciscan grammarian Sebastián de Totanés, and the 1850 Gramática de la lengua tagala by the Augustinian friar Manuel Buzeta. Both texts contained a bilingual confesionario used for the Catholic sacrament of penance. Through a two-tier approach that went from the lexicographic entries of the vocabulary to lengthier textual exemplars from two bilingual corpora, we shall see how sexualities and sexuality behaviours were greatly skewed to fit the moralizing stance of the authors.

All three missionary-colonial texts maintained that sex was a sin. In defining the Tagalog word libog 'lust, lustful' (219), for example, Noceda and Sanlúcar were quick to progress from the primary acceptation of lijurioso and carnal to a rather moralizing definition of deshonesto 'dishonest'. This image of sinfulness was further reinforced in the derivations of the Tagalog nominative contained in the same entry. Calibugan 'lust' was solely defined as deshonestidad 'dishonesty', and magcalibogan 'to lust for each other' was easily dismissed as hacer deshonestidades 'to commit dishonesties'.

The sinfulness of sex was so powerful a topos that missionaries felt compelled to adopt a foreignizing strategy in translating sex-related terms. This was evident in Noceda and Sanlúcar's translation of the human genitalia, almost all of which were rendered in Latin. The word otin 'penis' was defined as membrum virile 'virile member', and was qualified thereafter as verbum inhonestum 'a dishonest word' (271). On the other hand, puqui 'vagina' was both pars varenda mullieris 'the private part of a woman', and verbum turpissimum 'a very filthy word' (324). The same foreignizing strategy was applied in translating sexual acts. Balatic 'anal sex' was rendered as copula carnalis situ abominabili 'carnal copulation in an abominable place' (34), while buliglig 'masturbation' was pollutio propriis manibus 'pollution using one's own hands' (82).

There was nothing new in the use of Latin in grammars and dictionaries during this era. Schooled in the humanist traditions of Europe, the missionaries would have found the structures 
of Latin to be the most reliable and logical choice in explaining the languages of the colonized territories (Koerner 19). The Franciscan grammarian Melchor Oyanguren de Santa Ynes, for instance, introduced his approach to grammatizing Tagalog in his 1742 opus by saying that "the objective of writing this grammar, even though many others have already been published, is to match it as much as possible to Latinity." "What is instead significant, in my opinion, is the function that Latin had in camouflaging references to indigenous sexualities, which paradoxically made them even more conspicuous in the textual space.

A quick perusal of the third edition of the Diccionario de la lengua castellana (referred to as DLC hereafter), published by the Real Academia Española around the same time, shows that philologists in Spain did not hesitate to directly refer to sexual(ized) terms using Castilian with a rather straightforward and scientific tone. Lujuria was defined as "[e]l vicio que consiste en el uso ilícito ó apetito desordenado á los deleites de la carne" "the vice consisting in the illicit use or uncontrolled appetite for the delights of the flesh' (455); vagina was “ [e]l conducto que se extiende en las hembras desde el pubis basta la vulva ó matriz" "the passageway in women that extends from the pubis to the vulva or the womb;' (752) and verga was " Eejl miembro de la generación en los animales" 'the part for procreation in animals" (763). As for sexual acts, the only entry on coitus was filed under coito, defined as " $[e] l$ ayuntamiento del hombre con la mijer" 'the joining of the man with the woman' (176), and concúbito (187). Sexual practices that were deemed unorthodox, such as masturbation and bestiality, mostly went to pecado 'sin' under the acceptation contra natura ó contra naturaleza 'against nature'. Homosexuality was also filed under this term as sodomia, and was likewise defined in a separate entry as "[c]oncúbito entre personas de un mismo sexo, ó en vaso indebido" "coitus between persons of the same sex, or in an inappropriate vessel' (694). Although Latin was indeed used in other DLC entries, no ethical judgment was ever made in defining the words.

The Latin terms in the Noceda-Sanlúcar dictionary were therefore very telling. The missionaries needed to transpose the signifiers from the source to the target language, but always in keeping with their translational habitus and textual skopos. Language was seen by the missionaries as an instrument of proselytization, a belief best articulated by the Dominican friar Francisco Blancas de San José, author of the landmark Arte y reglas de la lengua tagala of 1610, in another work on the preaching of the Christian doctrine. He wrote that, "[...] the Tagalog language by itself is an endeavor of little importance, and it does not matter so much if one errs or succeeds in speaking it. Its value certainly becomes different once through it we preach God's truth to people who did not know Him."7

In the bilingual ambit of a missionary text where Castilian made sense of Tagalog through its own modes of signification, sexualized terms defined in Latin stood out as signs marking the exotic Other. Never mind if words pertaining to the genitalia and sexual acts also existed in

\footnotetext{
6 "[e]l motivo de escrebir este Arte (aviendo tantos) es el nivelarlo en lo possible â la latinidad" (Oyanguren de Santa Ynes 2).

7 “[p]orque si bien la lengua Tagala por lo que en si es ella, es negocio de poca importancia, y que vá poco en errar, ó en acertar á hablarla; pero en cuanto por medio de ella predicamos la verdad de Dios á Gentes que no le conocían, cierto que es ya como otra en el valor" (Blancas de San José 457).
} 
Castilian. Indigenous sexualities were deemed to be so different, so abhorrent and so sinful that they should be explained in a language other than the translators' own. The authority of Latin as a metalexical device was hinged on its being the language "at the center of the res publica christiana" (Binotti 141), and integrating it in the translational space "dramatizes the impossible desire for a pure, undifferentiated origin” (Bhabha Location of Culture 116).

Having a third language also had an estranging effect on the translation. The missionaries lexicalized Tagalog signifiers in such a way that the words were made to appear conceptually different and incomprehensible (or at least unacceptable) in Castilian. Commentaries on moralitylike the descriptors "abominable," "filthy," "dishonest," "polluting"-magnified the discursive unacceptability of the words in an apparent attempt to subject them to the external measure of social civility, which in turn ran along the lines of the Christian religion (Graham, Simmons and White 166; Peletz 85). To translate sexualities in this manner was to situate them in a site where the indigenous body was tautologically defined by the categories and knowledge systems imposed by the hegemony. It was to conceive a representational topos in which the Other's sexual persona was portrayed to be degenerate in relation to colonial standards, and incompatible with the images of civilized sexuality.

\section{Gender(ed) Roles}

A similar moralizing slant, this time in specifying gender(ed) expectations between men and women, can be gathered from Noceda and Sanlúcar's explanation of verbal affixes. An exceptional feature of Tagalog (Himmelmann 1) is its system of focus markings, where nouns in a sentence are assigned a thematic role in relation to the action through a complex series of affixes to the verbs (Schachter and Otanes 283-409). For this reason, Tagalog nouns are not mere subjects and objects, but are rather marked as agents, recipients, beneficiaries, cause or location of the action.

Beyond a mere formalistic or functional transposition of Tagalog clitics into Castilian, the missionaries utilized a doctrinal approach that explicitated designations of a sexualized social order. In the entry on dating 'to have an orgasm', Noceda and Sanlúcar explained that when conjugated with the prefix mag-, the verb referred to the man, while with the affix naca-, or the combination of the prefix $n a$ - and the sufix -an-, the verb referred to the woman (131). This definition at first glance reads as an innocent discussion on verb formation until one realizes what specific focal functions these clitics have in the syntax. A translation solution such as this delineated the roles a man and a woman ought to have in performing the sexual act. The Catholic belief on sexuality at the time prescribed that "seminal emission must be carried into the female vagina" (Lavrín "Sexuality in Colonial Mexico" 51). Men were thus expected to be the active agents of copulation, while women were mere passive receivers (Garza Carvajal 49). By sexualizing Tagalog affixes, the missionaries discursively constricted the consummation of sex within an entirely masculine domain, while at the same time reducing feminine participation to coital passivity. The woman's role was nacarating; she was literally and incidentally taken to climax with the help of the man. Or she could be naratnan, literally a beneficiary of ejaculation. 
This image of the active man and the passive woman proved to be a recurring theme in the dictionary. In defining ompang 'to rape', Noceda and Sanlúcar maintained that even without an explicit mention of the woman as the syntactic receiver, the verb should readily be understood as an action directed to one (265). Biro 'to have sex', on the other hand, was explained in the female voice through the sentence "Acoy biniro nang lalaqui" 'I was humped by a man', while the male voice was rendered as "Biniro ko" 'I had sex with her', or "Napabiro siya" 'She let me have sex with her' (61), thus essentializing sexual agency as a component of masculinity.

Even a word outside the semantic field of sexuality such as tapat 'trustworthy' (409) was explained through gendered exemplars. In the sentence "Sa atin natatapat ang aral nang Padre" "The priest's lesson was directed to us', the missionaries portrayed men as the source of truth and as a figure of authority who could speak about this truth. Women, meanwhile, were said to have fallen short of such virtue: the Tagalog exemplar "Natatapattapat ako sa asanang walang bait" was sexualized in its translation to archaic Castilian as 'Me ha cabido una muger tonta.' The translational choice sounds odd since asana (or asawa in modern orthography) is not genderspecific in Tagalog, and refers in fact to either husband or wife. There was no indication whatsoever that sustained the gendered conclusion that the asaua should be a woman. That the translation designated asaua as muger 'woman/wife' (mujer in modern orthography), and described her as tonta 'stupid' was simply to sexualize the lexicon in favor of the male voice.

It was under this condition of occlusion that translation became a deliberate exercise of choice, for as Steiner remarks, "we remember culturally, as we do individually, by conventions of emphasis, foreshortening, and omission" (29). Translation emphasizes by omitting, remembers by forgetting, and includes by excluding. Colonial translators created a space that "designated one particular epistemic/theological perspective as correct, conceiving as deviant and insufficient other forms of knowledge" (Mignolo and Schiwy 5). "[S]election and manipulation mechanisms [...] are inherent to every translation process" Ben-Ari (135) writes, and these mechanisms, or exclusion procedures (Wolf 60), emanate from the translators' intrinsic power to rewrite (Lefevere).

\section{Penitence, Power and the Policing of Desire}

The same male voice resonated in the confession guides appended to the grammars of Sebastián de Totanés and Manuel Buzeta. It is imperative to recall at this point that penance in Catholic teachings is articulated and performed from a patently masculine stance, since all sacraments are administered through the priest. Given that the sacrament of confession "was meant to compel the native penitent to produce a past in relation to the Christian history of salvation" (Rafael "Confession" 325), the colonial confessor participated in the discourse from a position of power and control as an arbiter of uprightness and enforcer of social order, a clear example of "language in actu" (Bhabha Location of Culture 326) that located the interactants in a hierarchical and performative space.

To facilitate the administration of the sacrament, missionary authors wrote their confession guides in a bilingual question-and-answer format. The priest was to read questions based on the 
Ten Commandments in Tagalog, while the Filipino confessant was to answer them with a yes or a no, and to provide specific descriptions of any perceived shortcomings whenever necessary. Many items were but redundant formulations of the same question. Totanés, for instance, asked "Ano kaya maaalaman co cun macaylan iyan?" 'May I know how many times you slept with her?', then rehashed the exact question for good measure in the three items that appeared thereafter (items 368-370, 135-136).

The policing of sexual desire even went to the extent of specifying the 'correct' coital position. Buzeta inquired "Cun nagsisiping cayong magasava, ay pinagyba ninyo ang ogali, at totoong pagcapalagay nang cataoang sucat ycapagbuntis nang babayi, sa macatovid, cun ang babayi sa ybabao?" 'Whenever you lie with your spouse, do you change the proper way that nature requires for conception by putting the woman on top of the man?' (155-156). Elsewhere, the Augustinian also asked if the woman whom a man was thinking about during masturbation was married, unmarried or a virgin, or if the confessant had sex on the eve of receiving communion (157).

As in the case of the Noceda-Sanlúcar dictionary entries, questions like these created a locus where the Castilian language accosted the realities of the grammatized Tagalogs, and made them a subject of their colonizers' moralizing gaze. By subjecting Filipino sexual practices to prescriptive textualization, the missionaries dichotomized the indigenous carnal desires between the Christian categories of good and evil, and by extension, between the constructed measures of colonial sophistication and backwardness. A civilized colonial subject was one whose sexual conduct lent to policing within the permissible limits of Christian morality.

The tension produced by such moralistic approach to writing was palpable in several items of the confession guides. In Totanés' item 373, which dealt with masturbation, the Franciscan asked in Tagalog "At nalabasan kaya ang catavan mo nang marumi?" 'Has any filth gone out of your body?” (136). The Spanish version of this question simply read “*Y tenias polución?” 'Did you have pollution?' Note that the Tagalog text was more specific with regard to the imagery of filth coming out of the body as constitutive of sin, while sin was implicitly understood in Spanish without resorting to such imagery. Note also that Totanés made no mention in either version of the substance that should come out of the body that would make the act sinful, thus suggesting that masturbation should be widely understood as a morally deviant act that needed no further explicitation.

Buzeta, for his part, would have quizzed an unmarried man by asking him, "Ytong siniraan mo nang cabooan nang cataoan niya, ay pinaquitipanan mo monang cayo ang magaasava, na siyang ypinayag niya sa gayong gava?' 'Before committing the act, did you promise marriage to this woman whose wholeness (cabooan, from the Tagalog root buo 'whole') you destroyed?' (154). The item in Castilian referred to the woman as "esta muger que desfloraste" 'this woman whom you deflowered'. The sinfulness of the act was made more obvious in Tagalog, as no outright suggestion was made in Castilian that sex was destructive of a woman's being. The Indio who confessed to having slept with a virgin was textualized in the confession guide to be guilty not merely of sex outside marriage, but also of destroying his partner's wholeness. In this way, the physical act of intercourse was 
translated as an unabashed manifestation of self-entitlement that took the woman out of her primordial state of completeness.

Examples from Totanés and Buzeta remind us that "[i]n the colonial discourse, that space of the other is always occupied by an idée fixe: despot, heathen, barbarian, chaos, violence" (Bhabha Location of Culture 143). The grammatized Filipinos were construed to be prone to sexual deviance, for which reason subjugation was offered as a corrective force to civilize them and bring them to uprightness. Seen in this light, the notion of civility becomes a moral construct, a duty of the colonized subject towards both the temporal and the divine. In the words of Bhabha, "the field of the 'true' emerges as a visible effect of knowledge/power only after the regulatory and displacing division of the true and the false" ("Signs" 41). What was regarded as true and just and good depended on the colonial binarism between the pure Self and the contaminating Other (Rojinsky 126). The colonized body was dirty and the colonized mind, weak. And it was only by subjecting the dirty body and the weak mind to the moral examination of the colony that they could be made whole.

\section{Conclusion: Missionary Position}

We have seen in the foregoing examples how grammatizing colonial sexualities in Philippine missionary texts should also be regarded as a translational locus. In providing a metalinguistic analysis of the Tagalog language, missionary authors likewise performed a cultural translation of early Filipinos, and described their sexualities for the benefit of their Western readers. That translation is "a necessary condition of writing" (Wilson 108) is underscored even further in our analysis of exemplars in Tagalog missionary linguistics, for whenever translation transforms the ostensible signifiers between languages, it will also have to transpose cultural conceptions and constructions in keeping with an ideological bias (Al-Mohannadi; Lefevere). Indeed, translation "is not an innocent, transparent activity but is highly charged with significance at every stage; it rarely, if ever, involves a relationship of equality between texts, authors or systems" (Bassnett and Trivedi 2).

In the case of Hispanic colonial writings in the Philippines, authorial inequality was anchored on the missionaries' privileged position of textualization. We saw in the examples above that the sexual practices of the grammatized Tagalogs were made to appear exotic, different and sinful, although they were essentially similar to the practices already seen and recorded in Spain. And this was why the missionaries' position was a one of power, for "translation is power-not simply an instrument of power or of a certain power, but intrinsically power, without which there is no translation" (Gouanvic 102). Accorded with the privilege to write in and on the grammatized language, the missionaries effected a normativization of indigenous sexual desires by emplacing them within the bounds of Christian morality, and by presenting such desires as conceptually diverse from the colonizers' own carnal pleasures.

Given that "the legitimacy conferred on dominant knowledges and languages ensured that the 'native' gained access to his own past through the texts of the colonial rulers" (Niranjana 38), 
this chapter in the evolution of Philippine sexuality would necessarily be accessed through the colonial imaginings of the missionary authors. Through the missionaries' sexualization of the texts, they managed to give a textual form to colonial sexualities that prescribed how they ought to be experienced, and allowed for their policing outside the realm of the written word. 


\section{REFERENCES}

Aduarte, Diego de. Tomo primero de la historia de la Provincia del Sancto Rosario de Filipinas, Iapon, y Cbina de la Sagrada Orden de Predicadores. Zaragoza: Domingo Gascón, 1693. Print.

Al-Mohannadi, S. "Translation and Ideology." Social Semiotics 18.4 (2008): 529-42. Print.

Anonymous. Los frailes filipinos. Madrid: Imprenta de la viuda de M. Minuesa de los Ríos, 1898. Print.

- "The Manners, Customs and Beliefs of the Filipinos of Long Ago." Trans. Quirino, Carlos. Readings in Philippine Prehistory. Ed. Mauro Garcia. Vol. I. Manila: The Filipiniana Book Guild, 1979. 307-57. Print.

Auroux, Sylvain. "Introduction." Histoire des idées linguistiques: le développement de la grammaire occidentale. Ed. Sylvain Auroux. Vol. 2. Liège: Mardaga, 1992. 11-64. Print.

Bassnett, Susan, and Harish Trivedi. "Introduction." Post-Colonial Translation: Theory and Practice. Eds. Susan Bassnett and Harish Trivedi. London and New York: Routledge, 1999. Print.

Ben-Ari, Nitza. "When Literary Censorship Is Not Strictly Enforced, Self-Censorship Rushes In." TTR: traduction, terminologie, rédaction 23.2 (2010): 133-66. Print.

Bhabha, Homi K. The Location of Culture. London, New York: Routledge, 2004. Print.

—_. "Signs Taken for Wonders." The Post-Colonial Studies Reader. Eds. Bill Ashcroft, Gareth Griffiths and Helen Tiffin. London and New York: Routledge, 2006 [1985]. 38-43. Print.

Binotti, Lucia. Cultural Capital, Language and National Identity in Imperial Spain. Woodbridge, Suffolk, UK and Rochester, NY: Tamesis, 2012. Print.

Blancas de San José, Francisco. Memorial de la vida christiana en lengua tagala [Librong mahal na ang ngala'y memorial de la vida christiana]. 2nd ed. Manila: Imprenta de José $\mathrm{M}^{\mathrm{a}}$ Dayot, Tomás Oliva [typesetter], 1832 [1605]. Print.

Buzeta, Manuel. Gramática de la lengua tagala. Madrid: Imprenta de D. José C. de la Peña, 1850. Print.

Caceres-Lorenzo, Maria-Teresa. "Pugna entre lenguas romances e indigenismo en el espanol atlántico (1496-1600)." Bulletin of Hispanic Studies 89 (2012): 795-811. Print.

Chirino, Pedro. Relacion de las Islas Filipinas $i$ de lo que en ellas an trabajado los padres de la Compañia de Iesus. Roma: Imprenta de Esteban Paulino, 1604. Print. 
Colín, Francisco. Labor euangelica, ministerios apostolicos de los obreros de la Compañia de Iesus : fundacion, y progressos de su prouincia en las Islas Filipinas / historiados por el padre Francisco Colin pronincial de la misma compañia ...; parte primera sacada de los manuscriptos del padre Pedro Chirino Vol. 1. 4 vols. Madrid: Ioseph Fernandez de Buendia, 1663. Print.

Cronin, Michael. "Double Take: Figuring the Other and the Politics of Translation." In Translation: Reflections, Refractions, Transformations. Eds. Paul St-Pierre and Prafulla C. Kar. Delhi: Pencraft International, 2005. 229-37. Print.

Crossley, John N. Hernando de los Ríos Coronel and the Spanish Pbilippines in the Golden Age. Farnham, England; Burlington, Vt.: Ashgate, 2011. Print.

Crow, John Armstrong. The Epic of Latin America. 4th ed. Berkeley: University of California Press, 1992. Print.

De San Antonio, Juan Francisco. Chronicas de la apostolica prouincia de S. Gregorio de Religiosos Descalzos de N.S.P.S. Francisco en las Islas Philipinas, China, Japon, \& C. . Sampaloc, Manila: Convento de Nra. Señora de Loreto del Pueblo de Sampaloc [Fr. Juan del Sotillo, typsetter], 1738-1744. Print.

Esparza Torres, Miguel Angel. "Nebrija y los modelos de los misioneros lingüistas del náhuatl." Missionary Linguistics III/ Lingüistica Misionera III: Morphology and Syntax-Selected Papers from the Third and Fourth International Conference on Missionary Linguistics. Eds. Otto Zwartjes, Gregory James and Emilio Ridruejo. Amsterdam/Philadelphia: John Benjamins Publishing Company, 2007. 3-40. Print.

Franco Figueroa, Mariano. El español de Filipinas: documentos coloniales. Monografías Filosofía, Filología Y Lingüística. Cádiz, Spain: Universidad de Cádiz, 2013. Print.

García-Medall, Joaquín. "Notas de lexicografía hispano-filipina--El bocabulario de lengua bisaya, biligueyna y haraya de la isla de Panay y Sugbu y para las demas Islas, de Fray Alonso de Méntrida, Osa (Ca. 1637)." Missionary Linguistics/Lingüistica Misionera-Selected Papers from the First International Conference on Missionary Linguistics. Eds. Otto Zwartjes and Even Hovdhaugen. Vol. 106. Amsterdam/Philadelphia: John Benjamins Publishing Company, 2003. 201-32. Print.

García Abasolo, Antonio. "Formación de las Indias Orientales españolas-filipinas en el siglo XVI." Historia general de Filipinas. Ed. Leoncio Cabrero. Madrid: Ediciones de Cultura Hispánica, 2000. 169-205. Print.

Garza Carvajal, Federico. Butterflies will Burn: Prosecuting Sodomites in Early Modern Spain and Mexico. Austin: University of Texas Press, 2003. Print. 
Gouanvic, Jean-Marc. "Legitimacy, Marronnage and the Power of Translation." Changing the Terms: Translating in the Postcolonial Era. Eds. Sherry Simon and Paul St-Pierre. Ottawa: University of Ottawa Press, 2000. 101-11. Print.

Graham, Elizabeth, Scott E. Simmons, and Christine D. White. "The Spanish Conquest and the Maya Collapse: How 'Religious’ Is Change?" World Archaeology 45.1 (2013): 161-85. Print.

Himmelmann, Nikolaus P. "The Philippine Challenge to Universal Grammar." Institut für Linguistik (Köln). Abteilung Allgemeine Sprachwissenschaft: Arbeitspapier; N.F., Nr. 15 (1991). Print.

Kamen, Henry Arthur Francis. Spain's Road to Empire: The Making of a World Power, 1492-1763. London: Allen Lane, 2002. Print.

Koerner, E.F. Konrad. Gramática de la lengua castellana de Antonio de Nebrija y el estudio de las lenguas indígenas de las Américas; o, hacia una historia de la lingüistica amerindia. Congreso Internacional de Historiografía Lingüística. Eds. Ricardo Escavy, José Miguel Hernández Terrés and Antonio Roldán. Vol. II: Nebrija y las obras amerindias. 3 vols. Murcia [Spain]: Secretariado de Publicaciones e Intercambio Científico, Universidad de Murcia, 1992. Print.

Lavrín, Asunción. "Introduction: The Scenario, the Actors, and the Issues." Sexuality and Marriage in Colonial Latin America. Ed. Asunción Lavrín. Lincoln: University of Nebraska Press, 1989. 1-43. Print.

—. "Sexuality in Colonial Mexico: A Church Dilemma." Sexuality and Marriage in Colonial Latin America. Ed. Asunción Lavrín. Lincoln: University of Nebraska Press, 1989. 47-95. Print.

Lefevere, André. Translation, Rewriting, and the Manipulation of Literary Fame. London and New York: Routledge, 1992. Print.

López de Mariscal, Blanca. "El problema de la nominación en el teatro de evangelización: un acercamiento ideológico." Caravelle (1988-). 76/77 (2001): 205-12. Print.

Mignolo, Walter, and Freya Schiwy. "Double Translation : Transculturation and the Colonial Difference." Translation and Ethnography: The Anthropological Challenge of Intercultural Understanding. Eds. Tullio Maranhão and Bernhard Streck. Tucson: The University of Arizona Press, 2003. 3-29. Print.

Morga, Antonio de. Sucesos de las islas Filipinas. Ed. Wenceslao Retana. Nueva edición. Madrid: Librería General de Victoriano Suárez, 1909 [1609]. Print.

Mukherjee, Tutun. "Gender, History and Translation." Re-Engendering Translation: Transcultural Practice, Gender/Sexuality and the Politics of Alterity. Ed. Christopher Larkosh. London and New York: Routledge, 2014. 127-43. Print. 
Niranjana, Tejaswini. "Colonialism and the Politics of Translation." An Other Tongue: Nation and Ethnicity in the Linguistic Borderlands. Ed. Alfred Arteaga. Durham: Duke University Press, 1994. 35-52. Print.

Noceda, Juan de, and Pedro de Sanlúcar. Vocabulario de la lengua tagala. 2nd ed. Valladolid: Higinio Roldán, 1832 [1754]. Print.

Ortiz, Thomas. Práctica del ministerio, que siguen los religiosos del Orden de N.P.S. Augustin, en Philippinas. Manila: Convento de Nra. Señora de los Angeles, 1731. Print.

Peletz, Michael G. Gender Pluralism: Southeast Asia since Early Modern Times. New York and London: Routledge, 2009. Print.

Phelan, John Leddy. The Hispanization of the Philippines: Spanish Aims and Filipino Responses, 15651700. Madison: University of Wisconsin Press, 1959. Print.

Rafael, Vicente L. "Confession, Conversion, and Reciprocity in Early Tagalog Colonial Society." Comparative Studies in Society and History 29.2 (1987): 320-39. Print.

Real Academia Española. Diccionario de la lengua castellana. 7th ed. Madrid: Real Academia Española Imp. Real, 1832. Print.

Retana, Wenceslao. "Epítome de la bibliografía general de Filipinas." Archivo del bibliófilo filipino : recopilación de documentos históricos, cientificos, literarios y políticos y estudios bibliográficos. Vol. 1. Madrid: Viuda de M. Minuesa de los Ríos, 1895. 1-84 (Section II). Print.

Ricard, Robert. The Spiritual Conquest of Mexico: An Essay on the Apostolate and the Evangelizing Methods of the Mendicant Orders in New Spain, 1523-1572. Trans. Leslie Byrd Simpson. Berkeley: University of California Press, 1966. Print.

Rojinsky, David. Companion to Empire: A Genealogy of the Written Word in Spain and New Spain, C.5501550. Amsterdam and New York: Rodopi, 2010. Print.

Sales, Marlon James. "Aproximaciones al verbo 'ser' en las gramáticas misioneras del tagalo." Humanities Diliman 5.1 and 2 (2008): 78-93. Print.

Santaemilia, José. "The Translation of Sex/the Sex of Translation-Fanny Hill in Spanish." Gender, Sex and Translation: The Manipulation of Identities. Ed. José Santaemilia. Manchester, Northampton: St. Jerome Publishing, 2005. 117-36. Print.

Schachter, Paul, and Fe T. Otanes. Tagalog Reference Grammar. Berkeley: University of California Press, 1972. Print.

Simon, Sherry. "Introduction." Changing the Terms: Translating in the Postcolonial Era. Eds. Sherry Simon and Paul St-Pierre. Ottawa: University of Ottawa Press, 2000. 9-29. Print. 
Steiner, George. After Babel: Aspects of Language and Translation. New York: Oxford University Press, 1975. Print.

Stoler, Ann Laura. Carnal Knowledge and Imperial Power: Race and the Intimate in Colonial Rule. Berkeley, Los Angeles, London: University of California Press, 2002. Print.

Sueiro Justel, Joaquín. Historia de la lingüistica española en Filipinas (1580-1898). 2nd ed. Lugo: Axac, 2007. Print.

Tiffin, Chris, and Alan Lawson. "Introduction. The Textuality of Empire." De-Scribing Empire: Post-Colonialism and Textuality. Eds. Chris Tiffin and Alan Lawson. London and New York: Routledge, 1994. 1-11. Print.

Totanés, Sebastián de. Arte de la lengua tagala, y manual tagalog, para la administracion de los santos sacramentos. Sampaloc, Manila: Convento de Nra. Sra. de Loreto, 1745. Print.

Wilson, Rita. "Response." Translation Studies 6.1 (2012): 107-11. Print.

Wolf, Michaela. "Censorship as Cultural Blockage: Banned Literature in the Late Habsburg Monarchy." TTR: traduction, terminologie, rédaction 15.2 (2002): 45-61. Print.

Zimmermann, Klaus. "Traducción, préstamos y teoría del lenguaje: la práctica transcultural de los lingüistas misioneros en el México del siglo XVI." Missionary Linguistics II/ Lingüística

Misionera Ii: Orthography and Phonology-Selected Papers from the Second International Conference on Missionary Linguistics. Eds. Otto Zwartjes and Cristina Altman. Vol. 109. Amsterdam/Philadelphia: John Benjamins Publishing Company, 2005. 107-36. Print.

Zwartjes, Otto. "The Missionaries' Contribution to Translation Studies in the Spanish Colonial Period: The Mise En Page of Translated Texts and Its Functions in Foreign Language Teaching." Missionary Linguistics V/Lingüistica Misionera V-Translation Theories and Practices. Proceedings from the Seventh International Conference on Missionary Linguistics (Bremen, Germany). Eds. Otto Zwartjes Klaus Zimmerman and Martina Schrader-Kniffki. Vol. 5. Amsterdam /Philadelphia: John Benjamins Publishing Company, 2012. 1-50. Print. 